\title{
Nation-Building and the Governance of Emerging Technologies: the Case of Nanotechnology in India
}

\author{
Koen Beumer
}

Received: 13 July 2017 / Accepted: 5 October 2018 / Published online: 22 November 2018

(C) The Author(s) 2018

\begin{abstract}
Emerging technologies like nanotechnologies are governed in different ways around the world. This article draws attention to an important element that can help to explain the emergence of this diversity in governance practices: the role of nanotechnology in nationbuilding. By investigating the relation between nanotechnology and the nation in India, the article demonstrates that various particularities of the Indian governance of nanotechnology can be explained by the relation between science, technology, and nation-building. The article discusses four instances in which the governance of nanotechnology in India is informed by the role science and technology has in nation-building: the historical image of India as a country that can attain modernity and development by engaging with modern science and technology supported the government's decision to free funds for nanotechnology research; the view of India as a country that cannot rely on foreign assistance to get access to the latest technologies reinforced the strategy to pro-actively pursue nanotechnology research and development itself; the historical use of science and technology as crucial elements in overcoming deeply rooted societal divisions enabled the science-centered way in which nanotechnology was governed; and the Indian ambition to become a global superpower informed the governance of nanotechnology as an object of international competition. The
\end{abstract}

\footnotetext{
K. Beumer $(\bowtie)$

Copernicus Institute of Sustainable Development, Innovation Studies Group, Utrecht University, 3584 CSUtrecht, the Netherlands

e-mail: k.beumer@uu.nl
}

governance of nanotechnology in turn defines 'Indianness' in a post-liberalization world.

Keywords Governance Divergence $\cdot$ Nation-building . Nanotechnology $\cdot$ India $\cdot$ Emerging technologies

\section{Introduction}

Over the last twenty years, the term governance has emerged as an overarching concept to capture the various attempts to steer emerging sciences and technologies. Governance can be understood as the traditions and institutions by which authority is exercised in order to steer a phenomenon in a particular direction [1]. The concept broadly refers to the insight that, first of all, the state is not the only actor that exercises authority but that other actors matter too, like industry, civil society organizations, and the public. And secondly, the term governance captures the view that not only policies and regulations matter but that also other mechanisms should be taken into account when aiming to understand the way emerging science and technology are steered [2-4].

Scholars working on nanotechnology have extensively studied various governance mechanisms, from risk regulations drawn up by international organizations [4] to informal governance arrangements between industry and civil society [5], and from public engagement mechanisms [6] to the use of technology assessment to enhance the reflexive nature of nanotechnology governance [7]. It has been estimated that governance issues 
comprise about $40 \%$ of all social science literature on nanotechnology [8]. One sustained finding from both nanotechnology (e.g. [9]) and other fields (e.g. [10-13]) is that emerging sciences and technologies are governed in different ways around the world. Even when faced with the same technological alternatives, so Jasanoff has pointedly concluded, "societies at similar levels of economic and social development often choose to go in different directions, based on divergent framings of what is at stake, and correspondingly different assessments of risks, costs, and benefits of various possible trajectories" ([10]:255).

These differences have been related to a plethora of different factors, including regulatory styles [12], cultural personality traits [13], issues of trust [14], and diverging assessment over what constitutes valid knowledge [10]. Nation-building - understood here as the practices and meaning that serve to create a shared cultural identity within the territory governed by a state $[15,16]$ - has been a particularly powerful resource in explaining the distinct characteristics of governance practices in particular locales (e.g. [17-19]). The various histories, traditions, and aspirations that bind the imagined community of a nation together have been shown to shape attempts to govern modern science and technology in various ways. In the case of nanotechnology, however, this has thus far hardly been drawn upon to understand the divergence of governance practices around the world. This is the first contribution of this article: by investigating the relation between nanotechnology and the nation in India, I will demonstrate that various characteristic features of the Indian governance of nanotechnology can be explained by the way science and technology act as instruments in nation-building.

The governance of nanotechnology in India provides a particularly interesting case to interrogate the relation between nation-building and technology governance because it is situated at the forefront of a profound shift in the global distribution of technology development. Classic models of geographical distribution of modern science and technology assume that modern science and technology flow in a single direction from the 'advanced' nations in the core to the 'less-advanced' countries in the periphery (e.g. [20]). In this reading, emerging technologies are located in the core while only older technologies that have been proven successful in the core may flow to the periphery. Postcolonial scholars of science and technology have long challenged such models by drawing attention to the value of indigenous knowledge in the global South (e.g. [21]), by pointing out the local nature of Western knowledge [22, 23], and by showing the way knowledge from the global South also flows towards the global North [21, 24]. The increasing engagement of 'less-advanced' countries with emerging technologies points to another move away from classic diffusion models: countries in the global South also develop those emerging sciences and technologies that are traditionally deemed characteristic of the core [25]. This can be seen in emerging sciences and technologies like ICT, biotechnology, neuroscience, as well as in the convergence of these fields. But nanotechnology perhaps provides the most poignant illustration of this: in terms of publications, countries like China and India are even amongst the leaders in the world [26-28].

This first and foremost increases the importance to understand the governance of emerging science and technology in India: the way India governs emerging sciences and technologies has an increasing impact on the direction of scientific and technological developments worldwide. But it also raises new questions about the role of technology in nation-building and the impact thereof on the governance of technology. Research on the entanglements between science, technology, and nation-building in developing countries has largely taken a postcolonial approach by focusing on how the periphery embraces, rejects, or reworks science and technology from the West into ways that provide them with distinct national identities [29]. The dichotomies between rich and poor, developed and developing, centre and periphery that these studies build upon, however, are decreasingly tenable as countries like India increasingly invest in emerging technologies, and their changing position in the world is thus bound to impact upon nation-building. This is the second contribution of this article: I investigate the role of nation-building in the governance of emerging technologies in the context of a country that is undergoing rapid changes that shift its position in the global techno-scientific order. How does the relation between nation-building and science and technology in India impact the governance of nanotechnology in a context where the country slowly moves from the periphery to the centre?

\section{Nation-Building and Technology Governance}

Nanotechnology is usually defined as the understanding and control of matter at the nano-scale, with one 
nanometer equaling one billionth of a meter. At this scale some material gain new properties and these properties can be used to develop novel products and processes. Governments and industries worldwide have subsequently invested billions of dollars in the development of nanotechnologies [30]. As such, nanotechnology is a perfect example of an emerging technology: science-based technologies characterized by novelty, recent high-growth, and potentially broad impacts [31].

The starting point for exploring the connection between nation-building and the governance of nanotechnologies in an emerging economy is taken from the literature on science, technology, and the nation. This literature has revealed a wide spectrum of ways in which science, technology, and nation-building have been connected, from steel plants in Indonesia [18] to electricity networks in Ivory Coast [32], and from steam engines in Portugal [33] to nuclear technology and computers in South Africa [19]. Both military technologies and large technological infrastructures dominate in these accounts, which are largely set in Cold War and postcolonial contexts. As Krige and Wang [29] wrote in the introduction of a recent special issue on science, technology and nation-building in post-colonial times, "existing accounts have tended to concentrate on the quests for advanced weaponry, high technology, and large scientific establishments that came to define the symbolic and literal meanings of power in the nuclear age. Cold war competition has loomed large in these histories, given the significance of atomic weapons, nuclear reactors, rockets, and satellites as quintessential markers of security, modernity, and national prowess" ([29]: 171). And more recently scholars have also paid attention to the various ways in which population genetics and other life sciences and technologies have become entangled with national identities (e.g. [34-37]).

This article shifts the focus from dual-use technologies, large technological infrastructures, and life sciences to the emerging field of nanotechnology; from postcolonialism and the Cold War to the context of an emerging economy in a globalizing world; and from the way science and technology are implicated in the formation of nation-identities to the way nation-building shapes the governance of science and technology. I will therefore investigate how the relation between science, technology and nation-building shaped the direction in which nanotechnology was steered, as well as the traditions and institutions by which actors exercised authority in order steer nanotechnology in that direction.

\section{Methodology and Sources}

In doing so, the article will adopt the insight from the literature on science, technology and nation-building that science, technology, and national identities are mutually constructed. This perspective builds upon theoretical notions of both science, technology, and the nation that debunk their supposedly essentialist nature and instead highlight the way science, technology, and the nation are established through practices (e.g. $[15,16$, $38,39])$. What constitutes valid knowledge, successful technologies, and the identity of a nation is considered as the outcome of a process through which shared meanings are created.

Gabrielle Hecht articulates this approach particularly well in her The Radiance of France [17], in which she demonstrates the close interconnectedness of nuclear power and national identity in post-World War II France. Hecht for instance observes how nuclear reactors in France were described as "the modern heirs of the Eiffel Tower and the Arc de Triomphe" ([17]:13). In doing so nuclear energy was provided with cultural legitimacy because it was placed in direct historical lineage with past achievements that were considered quintessentially French. At the same time the perspective employed by Hecht - and in this article - brings into view that the reference towards France as a nation of large technological projects not only legitimizes and shapes nuclear technology but that this reference also strengthens and shapes the French national identity as resting upon its success in large technological projects. As the French went through pains to establish the 'Frenchness' of nuclear technologies, parts of which inevitably were developed elsewhere, in turn 'Frenchness' was redefined in terms of technological advancement. The entanglement between technology and national identity thus mutually constructs both technology and national identities, both of which are subject to change.

This has implications for testing the hypothesis that the role of technology in nation-building impacts the way technologies are governed. The relation between nation-building and governance should similarly not be approached as a one-way street in which unchanging ideas about the nation influence actors to choose one out of many possible ways to govern nanotechnology. There is no stable practice of nation-building that exerts influence on malleable practices of technology governance. Instead the influence of nation-building on governance should be approached as a two-way street where 
particular and changing notions of the nation shape governance choices as much as those particular and changing forms of governance shape notions of the nation. When aiming to demonstrate that nationbuilding influences technology governance, I will hence describe entanglements of technological nation-building and technology governance - instances where nationbuilding and governance are mutually constructed.

This article highlights four different instances when technology governance and nation-building in India mutually construct each other. In each of these four instances, so this article demonstrates, characteristic features of Indian nanotechnology governance cannot be understood without paying attention to the specific role science and technology play in nation-building. And reversely, following Hecht's investigation of the radiance of France, the governance of nanotechnology is here understood as part of a struggle to define 'Indianness' in the post-liberalization world. How and why did the people involved in the governance of nanotechnology forge the relationship between nanotechnology and the Indian nation? What role did invoking Indianness play in the governance of nanotechnology? How did nanotechnology figure in changing notions of Indianness?

In answering these questions, I draw upon empirical research conducted as part of a project on the governance of nanotechnology for development that took place from 2010 to 2015. As part of this project I conducted 29 semi-structured qualitative interviews with 35 key stakeholder involved in nanotechnology governance in India. These interviews were conducted in two periods, first between November 2010 and January 2011 in New Delhi, Hyderabad and Chandigarh and second in October and November 2012 in New Delhi, Hyderabad and Pune. Since both governance choices and national identities are potentially in flux and open to contestation, it was important to take into account the views of a variety of different stakeholders. Interviews were taken with individuals involved in Indian nanotechnology governance at a variety of different institutes, including government departments, administrative bodies, the Indian bureau of standards, civil society organizations, and industry (see Table 1). As a rule the interviews were conducted in the working environments of the interviewees.

These interviews were complemented by an extensive document analysis. Between 2010 and 2015, I conducted systematic searches for documents about
Table 1 Institutional affiliations of interviewees

Institute

Bureau of Indian Standards

Central Drug Research Institute

Department of Information Technology

Department of Science and Technology

Development Alternatives

DSM India Innovation Centre

Indian Institute of Chemical Technology

Indian Institute of Technology Delhi

Indian Institute of Toxicological Research

Jawaharlal Nehru University

National Council for Science and Technology Communication

National Institute for Science, Technology And Development Studies

National Institute of Pharmaceutical Education and Research

National Physics Laboratory

Public Health Foundation of India

Research and Information System for Developing Countries

South Asian University

Technology Information, Forecasting and Assessment Council

The Energy and Resource Institute

University of Hyderabad

Vigyan Prasar

nanotechnology governance in India. In addition to gathering documents while doing fieldwork in India, I used both academic and non-academic search engines and used a wide variety of search terms for both nanotechnology (e.g. nanotechnology, nanotech, nano-scale research, etc.) and India (e.g. India, Indian, Bhārata, etc.). Both documents gathered through interviews and search engines were then scanned for further references. Because there is no predefined arena where the connection between nanotechnology and the Indian nation is made, a wide variety of different document types were included, ranging from government policies to scientific articles, and from newspaper columns to political speeches. The interviews and documents were then systematically analyzed for the 'bridges' that were forged between nanotechnology and the nation and for their role in forming or maintaining characteristic features of Indian nanotechnology governance. Together the interviews and the documents provide a good basis for interrogating the relation between Indian nationbuilding and nanotechnology governance.

Although material aspects of science and technology sometimes play an important role in accounts of nation- 
building (like the nuclear reactors and the bodies of people in their vicinity in Gabrielle Hecht's analysis of the radiance of France), this was much less prominent in the case of Indian nanotechnology. The most important reason for this is that nanotechnology is still at the early stages of its development: very few applications are on the market and the ones that are available have a limited impact as of yet. Although nanotechnologies are certainly likely to have real material effects, it was generally too early for such material impacts to manifest.

Finally, the relation between nation-building and technology governance will further be interrogated by occasionally contrasting the empirical findings for Indian nanotechnology governance to alternative governance practices that have been pursued either for nanotechnology in other countries or within India for other technologies. By comparing the empirical findings for Indian nanotechnology governance to these alternative ways in which technology governance and nationbuilding are mutually constructed, these examples can further inform our understanding of the particular ways in which technology-nation entanglements influence the governance of nanotechnology in India.

\section{Nanotechnology and the Nation in India}

Technology for a Modern India

The governance of nanotechnology is marked by a strong role for the national government, and in particular for several influential individuals with prominent positions in both science and the government. The government first set up a funding scheme in 2001 and since 2007 a much larger amount of funding has been freed by the Planning Commission. In the same year, a new organization called the Nano Mission was established that was given the responsibility to govern nanotechnology. The Mission functioned under the Department of Science and Technology and distributed funding through two committees - a scientific and a technological advisory committee - that both were predominantly staffed by scientists and funded projects based on the academic merit of the proposals received.

How was nanotechnology governance mutually constructed with nation-building in this context? In the most basic sense the role of nanotechnology in nationbuilding helps to explain why India invests in nanotechnology: the role of nanotechnology in nation-building informed the objectives for nanotechnology governance. As mentioned, the first Indian investments in nanotechnology started in 2001, only a year after the announcement of the American National Nanotechnology initiative, when the Science and Engineering Research Council initiated a small funding programme (the Nano Science and Technology Initiative) in order to 'feel the pulse' and explore the possibilities for India to engage in this new field of research and development. At the time, however, larger funds could only be freed in India when they were included in Five Year Plans by the Planning Commission (a structure that has recently been replaced by the newly created Niti Ayog that created three-year action plans, seven year strategies, and 15year vision documents). These Five Year Plans were the main vehicle for economic policy-making in India, a structure that builds upon post-independence ideas of economic planning. The Five Year Plans were drafted in a centralized and largely technocratic manner by the Planning Commission, chaired by the Prime Minister. As the process of drafting the Eleventh Five Year Plan (2007-2012) was underway, so one leading civil servant recalled, "it was (...) increasingly felt during this period that the national efforts were subcritical compared to the scale of nanotech R\&D enterprise in most developed nations and even some developing nations" ([40]:1415). The Eleventh Five Year Plan subsequently included an expanded funding programme for nanotechnology with an outlay of 10 billion rupees, to be administered by the Department of Science and Technology. In the years that followed various other government departments followed suit with similar funding programmes.

The arguments supporting India's investments in nanotechnology all point to the contribution nanotechnology can make to transforming India into a modern and developed nation. Nanotechnology, so the Five Year Plan notes, "represents a 'make or break' opportunity, capable of catapulting India into a high growth orbit and on a fast track to becoming a developed nation" ([41]:252). These arguments draw upon a longstanding relation between science, technology and the nation in India that is commonly associated with Jawaharlal Nehru, India's first Prime Minister. Hailing large dams as the 'temples of modern India', Nehru perceived of science and technology as essential tools for the newly independent nation to attain development and modernization [42]. As Gyan Prakash notes in his wonderful book Another Reason [43], "emergence and existence of India is inseparable from the authority of 
science and its functioning as the name for freedom and enlightenment, power and progress" ([43]:3). This narrative can perhaps be best captured by the oft-cited statement by Nehru that "it is science alone that can solve the problems of hunger and poverty, insanitation and illiteracy, of superstition and deadening custom and tradition, of vast resources running to waste, of a rich country inhabited by starving people" (quoted [44]:564-565).

The unambiguously positive assessment of nanotechnology's role for the Indian nation should not be taken for granted, however. As the historian of Indian science David Arnold has observed, "it would be erroneous to think of India as having a single scientific tradition" ([45]:2). The relation between science, technology and the Indian nation is for instance marked by the postcolonial pendulum where modern science and technology were at times embraced as forces that could liberate India from the British Raj while at other moments are rejected as tools for colonial domination. In these latter cases, science and technology have been perceived as instruments of colonial oppression that may bring into being new dependencies towards their former colonizers. "Modern technology", as another historian of science in India notes, "was always marked with the trace of the foreign. Yet true independence required self-reliance and indigeneity, especially in relation to technology" [46]. The very same dams that Nehru considered as the modern temples of India are dismissed by these critics as incarnations of Western ideals that are ill-suited to the Indian context, wreaking havoc to local communities whose villages were displaced and whose own technologies for the provision and distribution of water and electricity were relegated to the museum [47].

In the case of nanotechnology, however, the pendulum swings entirely the other way. On this side of the spectrum, modern science and technology are regarded as "the jewels in the crown of modernity" (Harding in [48]:2). Nanotechnology was squarely put in this tradition and actors across the board put forward nanotechnology as a powerful technology that can contribute to turning India into a developed nation [49]. Scientists from Indian research institutes were found claiming that "the possible impacts of nanotechnology will even go beyond those of the first Industrial Revolution" ([50]:648), and former President Abdul Kalam (19312015) claimed in his biography that a conference he organized to bring together various nano-scientists was one of the most significant events in his presidency [51], civil society organizations like The Energy and Resource Institute thought along these lines when highlighting the key challenges for India to be able to use nanotechnology to address key development-related challenges [52], and industry actors - though not often speaking out on nanotechnology - talked about the technology's contribution to India's development whenever they did. Actors across the board embraced nanotechnology as an essential tool for India to become a developed nation. The reverse criticism that charts modern technology as a tool of Western oppression was almost entirely absent.

The way this idea of the Indian nation informed the objectives for nanotechnology governance can be better understood by having a closer look at the two most powerful actors in shaping the governance of Indian nanotechnology, C.N.R. Rao and Abdul Kalam. Both Rao and Kalam held key positions in both the scientific establishment and the government and exerted substantial influence on Indian nanotechnology. C.N.R. Rao, who is often referred to as the 'nano-godfather' of India, is a solid state chemist who had been working on nanotechnology since the early 1990s. Rao held various leading positions at Indian scientific institutes and he is widely accredited to be one of the most successful Indian scientists alive. His claims carried further authority in his function as chair of the scientific advisory council to the Prime Minister, a position he held from 1985 to 1989 under Rajiv Gandhi and later since 2005 under Manmohan Singh. Abdul Kalam, previously scientific advisor to the Prime Minister himself, was a physicist and aerospace engineer whose claims about the relation between India and nanotechnology carried similar authority, especially after being elected in the office of president of India in 2002, a post to which he served until 2007. Two authors from industry wrote in 2005 that "since his appointment as the President of the country, Dr. Kalam has been campaigning for programs to expedite the development and commercialization of nanotechnology in India" ([53]289).

Both C.N.R. Rao and Abdul Kalam were influential in formulating the Five Year Plans and both repeatedly put nanotechnology forward as an essential field for India to engage in so as to become a modern and developed nation. In doing so, they strongly drew upon the Nehruvian view of India as a country for which modern science and technology are crucial to attain development. Kalam articulated this view most 
explicitly in the Technology Vision 2020, a large scale forecasting exercise led by Kalam that aimed at articulating what was required for India to 'transform' into a developed nation by 2020 . Resonating with Nehru's famous quote, the final roadmap document reads that 'technology is the only vital input' ([54]:6). "Mastering of technologies," so he wrote, "is the task to which the country and its people have to give importance. This can be considered to be the very essence of development" ([54]:9). Nanotechnology was readily understood within this framework by Abdul Kalam. Whereas nanotechnology had not yet risen to prominence by the time the Vision 2020 was first published and hence is not mentioned in the document itself, Kalam explicitly referred to the vision when promoting nanotechnology, for instance noting that "nanotechnology research, development and commercialization will be important to transform India into a developed nation by 2020" (cited in [55]).

\section{Technology Development for Independence}

The objectives for funding nanotechnology were thus partly pivoted upon a Nehruvian view of the nation as a developing nation that needs to engage with emerging technologies in order to attain development. The proactive manner in which this occurred was further informed by notions of India as a nation that can only reap the benefits of technologies and attain development when developing those technologies themselves.

Although the idea that developing countries should develop emerging technologies increasingly finds support (e.g. [56-58]), this also directly contrasts several well-established economic theories that outline the benefits for developing countries to wait until developed countries have conducted most high-risk fundamental research and subsequently adopt those technologies that may be of use locally (e.g. [59]). Yet in the case of Indian nanotechnology, this pathway was not conceived to be open because not developing the technology itself was perceived to jeopardize their chances to reap the benefits of the technology. This anxiety was time and time again captured by describing nanotechnology with the metaphor of a train or a bus. Nanotechnology emerges as an unstoppable and fast moving train that is passing now and "if we miss it in the coming years, we will definitely lag behind" ([60]:16-18). Whereas nanotechnology was almost unanimously embraced as a technology that could bring development to India, the possibility that India would indeed benefit from nanotechnology was premised on the condition that India makes an effort to board the train that will not pass again.

This uncertainty about the possibility to benefit from emerging technologies can be seen in other countries in different forms. In a very basic sense, the benefits provide the carrot while the uncertainty concerning the ability to reap those benefits provides the stick, both urging governments and industries to start investing in the promising technology. In Europe for instance nanotechnology benefits were considered attractive in a context where large parts of its industrial production have been outsourced to low-wage countries and innovativeness is considered its main source of competitiveness. The Lisbon Strategy most explicitly articulated this in the objective to become the most innovative economy in the world. Whereas the technology hence offers clear benefits, these are presented as conditional upon Europe's ability to be more innovative than others. This implied that its investments in nanotechnology have to be considered in relation to efforts by other countries; Europe has to 'stay ahead in the nano-race' [61], as the programme officer for nanosciences and technologies at the European Commission wrote.

The metaphor of a passing bus or train, however, also expresses the concern that India may fully miss out on the benefits. Contrary to a race, that Europe can merely fail to win, the Indian train can be missed in its entirety. This concern should be understood against the background of more recent entanglements of technology and the Indian nation. For instance take the technological projects that Abdul Kalam was involved in throughout his career, most notably the development of ballistic missiles, India's first indigenously developed satellite, and the nuclear technology that eventually led to the series of controversial underground tests in May 1998. India was prompted into developing these technologies as it was caught in the Cold War logic that excluded India from the international exchange of dual use technologies. These achievements were widely celebrated in India, serving as public demonstrations of the ability of the Indian nation to overcome such foreign opposition to their use of the latest technologies. The day India performed its first nuclear tests, May 11, has since become the official National Technology Day and Kalam's leadership in these projects were central in his election as President of India. As a flag-bearer in these projects, Abdul Kalam had first-hand experience in witnessing the unavailability of scientific and technological developments to India. 
In the case of nanotechnology this relation between unavailable technology and the self-sufficient nation was repeatedly drawn upon. Also nowadays, so Kalam warned in 2012, the latest technologies "are not available from developed countries to India at least for a decade. Hence, research is vital, particularly in basic sciences, to take up India's global competitiveness to the desired level" ([51]:78). C.N.R. Rao similarly warned that India "should not be at the receiving end when the world is driven by nanotechnology. (...) The country must play a leading role in science" [62]. India, in the context of nanotechnology, is thus constituted as a country that has to take care of itself in the face of foreign opposition, that needs to engage in the development of modern science and technology itself in order to have access to it. That nanotechnology was also interpreted in this light strengthened the urgency with which Indian actors set up funding schemes for the technology.

\section{Science-Centered Governance}

It was mentioned in section 3.1 that the Five Year Plans were the main mechanism for allocating government resources (before being replaced by the new structure). The Five Year Plans were drafted in a centralized and technocratic process and the main input for the allocation of funds for science and technology consisted of a report of a special steering committee on science and technology for the Eleventh Five Year plan. This report was prepared by the Office of the Principal Scientific Advisor to the Government of India, which was at the time headed by C.N.R. Rao. The Eleventh Five Year Plan stipulated the creation of an institute that would take charge of the governance of nanotechnology and distributed the funds that the Plan freed. The institute was called the Mission of Nano Science and Technology and is better known as the Nano Mission. The institute was launched on 3 May 2007 and was administered by the Department of Science and Technology. The Nano Mission was "an umbrella programme for capacity building" [63] and had five formal objectives: basic research promotion, infrastructure development, human resources development, international collaboration, and applications and technology development. The responsibility for executing this funding programme was put in the hand of the Nano Mission Council, which was in turn supported by two subsidiary advisory groups: one focused on science and one on applications and technology. These two advisory groups were responsible for distributing the funds that were allocated to nanotechnology in the Five Year Plan.

A characteristic feature of the way the Nano Mission governed nanotechnology was its science-centered nature [9]. First of all, with the exception of technology development, all objectives of the Nano Mission aimed first and foremost to build the capacity of Indian scientists to do fundamental research in the field of nanotechnology $[52,62]$. The great majority of funds were hence provided for fundamental research at universities and public research institutes. Secondly, in distributing the funding through a tendered system where actors could submit proposals in an open competition, the scientific quality of the proposals was the main criterion. Other possibly relevant factors, such as the relation between the area of studies (like water, energy, or health) and national priorities (like food security, clean water, or employment) were not taken into consideration. And thirdly, it were predominantly scientists that were enabled to steer nanotechnology so that the technology could help turn India into a modern and developed nation. The Nano Mission Council was headed by C.N.R. Rao himself and consisted almost entirely of scientists and so did the scientific and technology advisory groups that eventually decided which projects did and did not receive funding.

It hardly requires elaboration that this is not the only way to govern emerging technologies. A great deal of theoretical work has been put into capturing the various ways in which the governance of science and technology has moved away from a science-centered basis and has become ever more intertwined with societal and industrial actors and objectives (e.g. [64, 65]). This can also be seen in the case of nanotechnology, where governments around the world are involving industries, civil society organizations, and publics in the governance of nanotechnology. The Indian governance of science and technology is itself to some extent marked by a shift towards less sciencecentric forms of governance, as if for instance exemplified by the work of R.A. Mashelkar [66, 67].

Efforts to move beyond science-centered governance of nanotechnology were not entirely absent in India. For instance the Department of Science and Technology took several steps to promote science-industry linkages: they organized conferences together with the Confederation of Indian Industry [68] where scientists and industry could meet and they established a centre especially aimed at providing information services that supported industry and science collaborations. But at the end of the 
day, these efforts do not disguise the fact that the governance of nanotechnology is overwhelmingly sciencecentered.

Shortly after the launch of the Nano Mission their website already noted that "research on fundamental aspects of Nano Science and training of large number of manpower will receive prime attention" [63] and this was reflected in the funding pattern. Whereas between 2001 and 2012 the scientific advisory groups of the Nano Science and Technology Initiative and later the Nano Mission funded 240 so-called 'scientist-centric projects' focused on fundamental research, in the same period the technology advisory group funded only seven projects focused on technology applications [40]. Even if the scientific advisory group also funded a number of application-oriented projects, the share of these projects did not increase over time [69], and the emphasis squarely remained on fundamental research. Many actors in India disagreed that this science-centric form of governance was the best way to go forward: the limited efforts to turn fundamental science into applications and to connect science to industry was the most hotly debated issue in Indian discussions about nanotechnology governance [27].

This science-centered governance of nanotechnology is a tributary to linear notions of innovation but it also draws upon long-standing ideas of how science could best contribute to turning India into a developed nation. We have already seen that in the Nehruvian tradition, it is 'science alone' that can contribute to development and in governing science and technology this has been interpreted in the most literal sense. In the first two decades following Indian independence, scientists sought to implement the Nehruvian project by carving out an autonomous space for science [70]. The argument was that the scientific progress required for India to turn into a developed country, was best achieved by leaving science alone. As historian of science Dhruv Raina described: "strategic areas of scientific research were protected from bureaucratic and political intervention; this created the illusion of the autonomy of science from the social institutions that legitimated it" ([71]:360).

This was further perpetuated by notions of rationality and truth that were foundational for the Indian nation-state, as is perhaps best captured by the notion of 'scientific temper'. This notion was introduced by Jawaharlal Nehru in 1946 and the aim to develop 'scientific temper' was even included in the Constitution of India as one of the fundamental duties of Indian citizens. The term referred to the ideal that citizens should adopt a scientific attitude to everyday life, which could help to overcome superstitions and religious beliefs that were perceived to hold back India's development. While it has been pointed out that this denigrates Indian citizens by suggesting they themselves are responsible for their suffering because of their supposed lack of scientific temper (e.g. [72]), the term simultaneously aimed to promote equality in a society that was marked by rigid inequalities and divisions along the lines of caste, religion, gender, and class. As several interviewees told me: one and one is two, regardless of whether one is a Hindu or Muslim. The notion of scientific temper thus puts forward India as a nation whose divisions could be bridged and whose backwardness could be overcome by science, on the premise that facts and values, science and politics could be strictly separated. The move to distinguish science from politics in the governance of nanotechnology thus emerged in the context of an Indian nation with potentially deep-rooted divisions that could be bridged by science.

In the case of nanotechnology governance the strict separation of science from politics was also visible in attempts to actively shape the Nano Mission as an expert body. While both the Nano Mission council and the two advisory groups consisted of both scientists from public research institutes and civil servants from the Department of Science and Technology, both the scientists and civil servants were explicitly referred to as scientists. This followed the practice of the Department of Science and Technology to exclusively staff this government department with scientists, not only by exclusively hiring people with a background in science, but also by referring to employees as scientists. For instance the rank of a civil servant is denoted with 'scientist A' (the starting level) up to 'scientist H' (a very high level civil servant). In their daily work these government employees functioned as civil servants but by continuously identifying them as scientists, a clear boundary was suggested between science and politics, thereby reaffirming that in India science is the exclusive domain of experts. As one civil servant explained to me: "All people in the Department of Science and Technology (...) are scientists. This ministry is not run by bureaucrats. This ministry is run by technocrats" (Interview, New Delhi, 7 November 2012). 
The exclusive reliance on scientific criteria to judge the quality of proposals further built upon these ideas of the Indian nation whose unity and ability to attain development was premised on the autonomy of science. The nanotechnology funds were distributed on a competitive basis where scientists had to submit a proposal and orally defend this in front of the Nano Mission advisory groups. Both the scientific and technology advisory groups based their decision on the scientific quality of the proposal and the scientific track record of the researchers, without taking into account problems of national importance. While it may be suggested that the early stage of development of the field of nanotechnology may play a role here, this did not prevent other countries from governing nanotechnology in ways that tried to steer technology developments towards specific problems of national importance right from the start, as was for instance the case in countries like South Africa and the Netherlands [49, 73]. Whereas in India the application-oriented projects that were funded increasingly revolved around applications in the domains of energy and health, there are no indications that this was a feature of governance itself. In contrast, as one senior scientist who was a member of both advisory groups mentioned in an interview: "in a group which is evaluating a research project, political considerations are never there. They are essentially driven by the academic merit of a project" (Interview, New Delhi, 10 December 2010). The science-centered way of governing nanotechnology hence cannot be understood without attending to the role of science ('science alone') and technology in Indian nation-building. Only by attempting to strictly exclude political considerations from decisionmaking could entrenched divisions be bridged and could science contribute to turning India into a developed nation.

\section{Global Leadership}

A final feature that characterizes the Indian governance of nanotechnology is that it is aimed at global leadership. This was first of all visible in that the success of Indian governance efforts were measured by comparing Indian achievements to those of other countries. C.N.R. Rao for instance repeatedly compared India to Europe, the United States, and China, noting that: "India is lagging behind the U.S. and Japan, where annually a couple of billion dollars are invested in nanotechnology research and development. Even China has a head start and is putting in a few hundreds of millions of dollars into its nanotechnology efforts" (cited in [74]). And when evaluating the effects of governance measures, government officials and academics routinely referred to statistics that explicitly set off Indian achievements against those of other countries, at times in terms of funding, but predominantly in terms of scientific publications and patents (e.g. [40, 75]). Such figures and comparisons construct nanotechnology as the subject of international competition, spurring India to invest in order to get a 'piece of the pie'.

The production and use of internationally comparative numbers of nanotechnology output is itself part of technology governance as it enables decision-makers to adjust the way they steer the technology. This is certainly not an uncommon part of nanotechnology governance. In various European and North American countries this is for instance standard practice in the "nanorace' $[76,77]$. And yet, in the Indian context, it should not be taken for granted. In the Indian context, where nanotechnology was pursued in order to transform from a developing into a developed country, one could easily imagine other ways to measure the extent to which nanotechnology contributed to this objective. For instance they could measure the effects of nanotechnologies on poverty reduction, on the provision of clean water and electricity, the expansion of capabilities of the poor, or other common development indicators. Instead, by putting the relative performance of India in terms of scientific publications and patents central, these statistics not only reiterate the science-centric nature of Indian nanotechnology governance, it also makes India's achievements in the field of nanotechnology relative to the achievements of other countries, which subsequently serve as a yardstick to measure Indian success in nanotechnology.

What is more, despite explicitly describing India as a developing country, several scientists, commentators, and politicians, including C.N.R. Rao and Abdul Kalam, repeatedly cited the opportunity for India to be a leader in the field. On the one hand this was partly due to the novelty of the technology. In contrast to wellestablished technologies like semiconductors that would require substantial investments for India to even match other countries' past achievements, nanotechnology was perceived to provide a more level playing field because also other countries were only beginning to discover technologies at the nano-scale. C.N.R. Rao argued that: "India has become one of the leaders in nanoscience and 
technology because this is an upcoming area where we are more or less on an equal footing with the rest of the world. (...) In nanoscience, we can become one of the leaders, if we try hard" ([60]:16).

On the other hand the objective to be a leader in the field was also partly informed by the recently thriving ideas of India as a world leader. This feature of Indian nanotechnology governance is hence entangled with ideas of nation-building that strongly depart from Nehruvian views of the Indian nation. Since the 1991 economic reforms India has witnessed high rates of economic growth that have fed wide speculations of India becoming a global power (e.g. see [78-80]). This has also spilled over to the domain of science and technology, with commentators characterizing India's rise as the emergence of a 'knowledge superpower' (see [81-86]). Even though India does not come close to match the United States, Europe and Japan on rankings of virtually all science and technology indicators, India did witness high growth rates in both research spending and scientific output. In 2002 researchers affiliated to Indian institutions published a total of nearly 19,000 publications whereas already in 2008 this had increased to over 36,000 [87], and in 2014 this increased to over 53,000 [88].

The ambition to become a world leader in nanotechnology emerged in the midst of this newly found optimism about India's position in the world. Abdul Kalam for instances noted that "today we have an opportunity to take the leadership in the knowledge revolution" (cited in [89]). And the steering committee on science and technology for the Eleventh Five Year Plan posited that "India must try to become a global innovation leader" ([90]:7), citing nanotechnology as a prime example. Whereas the notion, outlined above, that nanotechnology can help to turn India into a developed nation is mainly concerned with the impacts or consequences of nanotechnology within India, the ambition to become a world leader through nanotechnology situates the Indian nation in a global arena where development is measured in relation to the technological advances of other nations. If India wanted to be a united country that could overcome superstition and religion and turn into a developed nation, a world leader even, then nanotechnology had to be pro-actively pursued to ensure access to the technology, its governance had to be left to scientific experts alone, and their success should be measured by comparing Indian achievements to those of other countries.

\section{Conclusion}

This article has demonstrated that the governance of nanotechnology in India is informed by the role science and technology have in nation-building in a context where India is undergoing rapid changes that shift its position in the global techno-scientific order. I have highlighted four instances in which the role of science and technology in nation-building informed the governance of nanotechnology in contemporary India. The historical image of India as a country that can attain modernity and development by engaging with modern science and technology supported the government's decision to free funds for nanotechnology research; the view of India as a country that cannot rely on foreign assistance to get access to the latest technologies reinforced the strategy to pro-actively pursue nanotechnology research and development itself; the historical use of science and technology as crucial elements in overcoming deeply rooted societal divisions enabled the science-centered way in which nanotechnology was governed; and the Indian ambition to become a global superpower informed the governance of nanotechnology as an object of international competition. In short, if we want to understand the diverse ways nanotechnology is governed around the world, then it is worthwhile to take into account the role that nanotechnology plays for in the process of nation-building.

Secondly, this article explored the relation between nation-building and technology governance in the context of a country whose position in the global technoscientific order is rapidly changing. This article investigated this by departing from the view that the role of technology in nation-building does not one-sidedly inform governance practices but that nation-building and technology governance are mutually constructed. The governance of nanotechnology thereby is part of attempts to define 'Indianness' in a post-liberalization world. What we have seen is that the governance of nanotechnology on the one hand reiterates and reinforces ideas about the Indian nation that can be traced back to both postcolonial ideas about the way science and technology can stimulate development and bridge societal divides, as well as Cold War tensions about the limited access to new technologies. These older ideas about the Indian nation hence by no means disappeared now that India's position in the world has changed. Although India now cannot be readily fit into the dichotomies of rich and poor, developed and developing, 
centre and periphery, the ideas of the Indian nation that were informed by these dichotomies persist. On the other hand nanotechnology governance also did come with different ideas about the Indian nation that can only be understood in the light of more recent developments. The fear of having limited access to the latest technologies was reworked from the context of security in the Cold War into the context of competitiveness in the global market and the ambition to become a world leader in the field of nanotechnology strengthened the view of India as a potential global superpower. The changing position of India thus brought along different ideas of the Indian nation and older notions of technology in India were reinterpreted in the light of these changes.

It is important to emphasize that the governance of nanotechnology strengthens these views of the nation at the cost of others. India for instance also has tradition of technological nation-building in which simple technologies used by people in the villages convey the image of a nation that finds its own path of modernity. This tradition is commonly associated with Mahatma Gandhi and is most prominently expressed in the depiction of the spinning wheel on the pre-independence version of the flag of India. However, this is nowhere to be found in Indian nanotechnology governance, despite high expectations in academic literature about the use of nanotechnology to directly address the needs of the poor living in remote areas $[9,91]$. The mutual construction of nation-building and technology governance hence strengthens particular views of the nation at the cost of others. Whether this pattern of change and continuity in the role of science and technology in nation-building finds similar expression in other developing countries and emerging economies remains to be seen.

It should speak for itself that nation-building is not the only determinant of these governance practices and that not all characteristics of nanotechnology governance can be explained by the role the technology has in nationbuilding, as is highlighted in the various other relevant elements giving rise to national differences that have been previously identified (e.g. [11, 13]). The characteristic features of the various traditions and institutions that attempt to steer nanotechnology cannot a priori be reduced to a single driver and they can only be fully understood by an approach that is sufficiently open to incorporate a diverse set of factors [9], of which nationbuilding is only one. For analytical purposes, however, this article has focused the attention on one such element
- the role of technology in nation-building - in order to demonstrate that nation-building is an important element when aiming to understand different forms of nanotechnology governance in a changing world.

Understanding the divergence in governance practices is set to become more important as emerging economies increasingly engage with emerging science and technology. In 1997, not long before countries started investing in nanotechnology, Asia (excluding Japan) only accounted for $15,1 \%$ of world gross expenditure on research and development whereas North America and Europe accounted for 67,0\% [92]. By 2013, only sixteen years later, North America and Europe's share had dropped to $51,6 \%$ and Asia (excluding Japan) is now responsible for $32,6 \%$ of the world's gross expenditure on research and development [88]. This makes it increasingly important to understand diverging governance practices because the way developing countries govern emerging science and technology increasingly impacts both the direction of technological change worldwide as well as the global governance of transnational movements and impacts of these sciences and technologies. Using the example of nanotechnology in India, this article has highlighted that the role science and technology have in nation-building is an important factor informing the governance of emerging science and technology.

Acknowledgements This work was supported by NWOWOTRO (Nederlandse Organisatie voor Wetenschappelijk Onderzoek - Wetenschappelijk Onderzoek van de Tropen en Ontwikkelingslanden) under the project 'Nanotechnologies for development in India, Kenya and the Netherlands - towards a framework for democratic governance of risks in developing countries'. I am grateful to the editors and anonymous peer reviewers for their valuable comments and I would like to thank Wiebe Bijker and Aalok Khandekar for all their valuable feedback during the research phase.

Open Access This article is distributed under the terms of the Creative Commons Attribution 4.0 International License (http:// creativecommons.org/licenses/by/4.0/), which permits unrestricted use, distribution, and reproduction in any medium, provided you give appropriate credit to the original author(s) and the source, provide a link to the Creative Commons license, and indicate if changes were made.

\section{References}

1. World Bank (2006) Governance matters 2006. Worldwide governance indicators. A decade of measuring the quality of governance. The World Bank, Washington D.C. 
2. Pierre J (2000) Debating governance: authority, steering, and democracy. Oxford University Press, Oxford

3. Zumbansen P (2012) Governance: an interdisciplinary perspective. In: Levi-Faur D (ed) The Oxford handbook of governance. Oxford University Press, Oxford, pp 83-96

4. Levi-Faur D (2012) The Oxford handbook of governance. Oxford University Press, Oxford

5. Krabbenborg L (2013) DuPont and environmental defense fund co-constructing a risk framework for nanoscale materials: an occasion to reflect on interaction processes in a joint inquiry. NanoEthics 7:45-54

6. Cormick C (2012) The complexity of public engagement. Nat Nanotechnol 7:77-78

7. Rip A, Van Lente H (2013) Bridging the gap between innovation and ELSA: the TA program in the Dutch nanoR\&D program NanoNed. NanoEthics 7:7-16

8. Kjølberg K, Wickson F (2007) Social and ethical interactions with nano: mapping the early literature. NanoEthics 1: 89-104

9. Beumer K (2016) Nanotechnology and development. Styles of governance in India, South Africa, and Kenya. Maastricht University Press, Maastricht

10. Jasanoff S (2005) Designs on nature: science and democracy in Europe and the United States. Princeton University Press, Princeton

11. Halffman W (2005) Science-policy boundaries: national styles? Sci and Public Policy 32:457-467

12. Vogel D (1986) National styles of regulation: environmental policy in Great Britain and the United States. Cornell University Press, Ithaca

13. Kelman S (1981) Regulating America, regulating Sweden: a comparative study of occupational safety and health policy. MIT Press, Cambridge, MA

14. Löfstedt RE, Vogel D (2001) The changing character of regulation: a comparison of Europe and the United States. Risk Anal 21:399-405

15. Hobsbawm E, Ranger T (1983) The invention of tradition. Cambridge University Press, Cambridge

16. Anderson B (1991) Imagined communities. Verso, London

17. Hecht G (2009) The radiance of France. MIT Press, Cambridge, MA

18. Moon S (2009) Justice, geography, and steel: technology and national identity in Indonesian industrialization. Osiris 24:253-277

19. Edwards PN, Hecht G (2010) History and the technopolitics of identity: the case of apartheid South Africa. J Southern African Studies 36:619-639

20. Basalla G (1967) The spread of Western science. Science 156:611-622

21. Hayden C (2005) Bioprospecting's representational dilemma. Sci as Culture 14:185-200

22. Turnbull D (2000) Rationality and the disunity of the science. In: Selin H (ed) Mathematics across cultures. The history of non-Western mathematics. Kluwer Academic Publishers, Dordrecht, pp 37-54

23. Chakrabarty D (2007) Provincializing Europe: postcolonial thought and historical difference. Princeton University Press, Princeton

24. Tilley H (2011) (2010) Global histories, vernacular science, and African genealogies; or, is the history of science ready for the world? Isis 101:110-119
25. Pollock A (2014) Places of pharmaceutical knowledge-making: global health, postcolonial science, and hope in South African drug discovery. Soc Stud of Sci 44:848-873

26. Huang C, Notten A, Rasters NJ (2011) Nanoscience and technology publications and patents: a review of social science studies and search strategies. J Technol Transfer 36:145-172

27. Beumer K, Bhattacharya S (2013) Emerging technologies in India: developments, debates and silences about nanotechnology. Sci Public Policy 40:628-643

28. StatNano (2017). Ranking of countries in nanotechnology publications in 2016. http://statnano.com/news/57105. Accessed 13 Sept 2018

29. Krige J, Wang J (2015) Nation, knowledge, and imagined futures: science, technology, and nation-building, post-1945. Hist Technol 31:171-179

30. Roco MC (2005) International perspective on government nanotechnology funding in 2005. J Nanopart Res 7:707-712

31. Cozzens SE et al (2010) Emerging technologies: quantitative identification and measurement. Tech Anal Strat Manag 22: 361-376

32. Akrich M (1992) The de-scription of technical objects. In: Bijker WE, Law J (eds) Shaping technology / building society. Studies in sociotechnical change. MIT Press, Cambridge, MA, pp 205-224

33. Saraiva $T$ (2007) Inventing the technological nation: the example of Portugal (1851-1898). Hist Technol 23:263-273

34. Olarte Sierra MF, Del Castillo Hernández AD (2013) 'We are all the same, we all are Mestizos': imagined populations and nations in genetics research in Colombia. Sci as Culture 23:226-252

35. Kent M, García-Deister V, López-Beltrán C, Ventura Santos R, Schwartz-Marín E, Wade P (2015) Building the genomic nation: 'homo brasilis' and the 'genoma mexicano' in comparative cultural perspective. Soc Stud of Sci 45:839-861

36. Schwartz-Marín E, Wade P, Cruz-Santiago A, Cárdenas R (2015) Colombian forensic genetics as a form of public science: the role of race, nation and common sense in the stabilization of DNA populations. Soc. Stud. Sci. 45:862885

37. Landström C (2005) 'A more authentic Australia': cultural narratives in biological control research. Sci. as Culture 14: 59-75

38. Bijker WE (1995) Of bicycles, bakelites, and bulbs: toward a theory of sociotechnical change. MIT Press, Cambridge, MA

39. Bijker WE, Law J (1992) Shaping technology / building society. Studies in sociotechnical change. MIT Press, Cambridge, MA

40. Asthana P (2011) Nano research in India. Some encouraging trends. Nano Digest 14-17

41. Planning Commission (2008) Eleventh five year plan (20072012), volume III. Agriculture, rural development, industry, services, and physical infrastructure. Oxford University Press, New Delhi

42. Raina D (2003) Images and contexts: the historiography of science and modernity in India. Oxford University Press, New Delhi

43. Prakash G (1999) Another reason: science and the imagination of modern India. Princeton University Press, Princeton 
44. Ram A (1961) The making of optical glass in India: its lessons for industrial development. Shanti Swarup Bhatnagar memorial lecture. http://www.new.dli.ernet. in/rawdataupload/upload/insa/INSA_1/20005aca_531.pdf. Accessed 28 Oct 2013

45. Arnold D (2000) The new Cambridge history of India. Science, technology and medicine in colonial India. Cambridge University Press, Cambridge

46. Abraham I (2006) The ambivalence of nuclear histories. Osiris 21:49-65

47. Visvanathan S (1997) A carnival for science: essays on science, technology and development. Oxford University Press, New Delhi

48. Hinterberger A (2013) Curating postcolonial critique. Soc. Stud. Sci. 43:619-627

49. Beumer K (2015) The co-production of nanotechnology and development in India, South Africa, and Kenya. In: Bowman DM, Dijkstra A, Fautz C, Guivant J, Konrad K, van Lente H, Woll S (eds) Practices of innovation and responsibility. Insights from methods, governance and action. IOS Press / AKA, Berlin, pp 85-98

50. Bürgi B, Pradeep T (2006) Societal implications of nanoscience and nanotechnology in developing countries. Curr Sci 90:645-658

51. Kalam APJ (2012) Turning points. A journey through challenges. HarperCollins Publishers India, New Delhi

52. The Energy and Resource Institute (2009) Nanotechnology developments in India: a status report. Project report no. 2006ST21: D5. The Energy and Resources Institute, New Delhi

53. Chandra P, Narasimhan G (2005) Nanotechnology in India: government support, market acceptance and patent profile. Nanotechnology, Law \& Business 2:289-293

54. Kalam APJ, Rajan YS (2002[1998]) India 2020. A vision for the new millennium. Penguin Books, London

55. Newswire (2006) India tops in nanotechnology related Google ${ }^{\mathrm{TM}}$ search. Newswire. http://www.newswiretoday. com $/$ news $/ 6765 /$. Accessed 28 Oct 2013

56. World Bank (1998/1999) World development report 1998/1999. Knowledge for development. World Bank, Washington D.C.

57. OECD (2004) Global knowledge flows and economic development. OECD, Paris

58. UNCTAD (2007) The least developed countries report 2007. Knowledge, technological learning and innovation for development. UNCTAD, Geneva

59. Chang H-J (2002) Kicking away the ladder: development strategy in historical perspective. Anthem Press, London

60. Digest N (2009) Small tech. Big potential. Nano Digest 1: 16-18

61. Hullman A (2006) Who is winning the global nanorace? Nat Nanotechnol 1:81-83

62. Press Trust of India (2006) India cannot afford to miss revolution in nanotechnology: Rao. Outlook India. http://news.outlookindia.com/items.aspx? artid=346054. Accessed 28 October 2013

63. Government of India (2008) About Nano Mission. http://web.archive.org/web/20080127181557 /http:/nanomission.gov.in/. Accessed 27 March 2015

64. Gibbons M, Limoges C, Nowotny H, Schwartzman S, Scott P, Throw M (1994) The new production of knowledge: the dynamics of science and research in contemporary societies. Sage, London

65. Etzkowitz H, Leydesdorff L (2000) The dynamics of innovation: from national systems and "mode 2 " to a triple helix of university-industry-government relations. Res Policy 29: 109-123

66. Mashelkar RA (2005) India's R\&D: reaching for the top. Science 307:1415-1417

67. Mashelkar RA (2008) Indian science, technology, and society: the changing landscape. Technol Soc 30:299-308

68. Confederation of Indian Industry, Department of Science and Technology (2010) The nanotechnology conclave. The retrospect. http://www.tntdpc.com/nanotech_2011 /ntconclavetill2010.pdf. Accessed 27 March 2015

69. Anand M, Sarma SD (2013) Emerging innovation systems of nanotechnology in India. In: Sarma SD, Anand M (eds) Capabilities and governance of nanotechnology in the developing world. Insights from India. TERI Press, New Delhi, pp 7-40

70. Abraham I (1998) The making of the Indian atomic bomb. Zed Books, London

71. Raina D (2002) The naturalization of modern science in South Asia: a historical overview of the processes of domestication and globalization. In: Renn J (ed) The globalization of knowledge in history. Holtzbrinck Publishing Group, Stuttgart, pp 345-366

72. Sharma D (2000) Science, culture and conflict in India. Cult Dyn 12:164-181

73. Rip A (2010) NanoNed. In: Guston DH (ed) Encyclopedia of nanoscience and society. Sage, London, pp 511-512

74. Krishnadas K (2007) India rolls out nanotech initiative. EE Times. http://www.eetimes.com/document.asp?doc id=1167576. Accessed 1 Feb 2013

75. Bhattacharya S, Pushkaran JA, Shilpa BM (2012) Knowledge creation and innovation in nanotechnology: contemporary and emerging scenario in India. CSIRNISTADS, New Delhi

76. Robinson KD (2010) Constructive technology assessment of emerging nanotechnologies. Experiments in interactions. Dissertation, Twente University Press, Enschede

77. Rip A (2010) Nanotechnology for a knowledge society - in Europe. Paper presented at the second ICPC-Nanonet webinar. http://www.nanopodium.nl/CieMDN/ content/Presentation_ArieRip.pdf. Accessed 29 Oct 2013

78. O'Neill J (2001) Building better global economics BRICs. Goldman Sachs Global Economics Paper 66, New York

79. Zakaria F (2006) India rising. Newsweek. http://www. scribd.com/doc/152899743/Zakaria-India-Rising. Accessed 19 April 2015

80. Mahbubani K (2008) The new Asian hemisphere. The irresistible shift of global power to the East. Public Affairs, New York

81. Planning Commission (2001) India as knowledge superpower. Strategy for transformation task force report. New Concept Information Systems Pvt. Ltd, Noida

82. Kalam APJ (2002) Ignited minds: unleashing the power within India. Penguin Global, London

83. Bound K (2007) India: the uneven innovator. DEMOS, London

84. New Scientist (2005) India special: the next knowledge superpower. New Scientist, 16 February 2005 
85. Press Trust of India (2012) Students can make India a knowledge superpower.http://articles.economictimes. indiatimes.com/2012-06-10/news/32156151_1_ knowledge-superpower-student-community-baramati. Accessed 28 October 2013

86. Bhatia B (2012) India, a knowledge super power. Times of India. http://articles.timesofindia.indiatimes.com/2012-0604/news/32033005_1_higher-education-nationalknowledge-knowledge-network. Accessed 24 June 2015

87. UNESCO (2010) UNESCO science report 2010. The current status of science around the world. UNESCO, Paris

88. UNESCO (2015) UNESCO science report: towards 2030. UNESCO, Paris
89. Das P (2006) Can lead knowledge revolution. The Hindu, 30 November 2015. Accessed 24 June 2015

90. Planning Commission (2006) Report of the steering committee on science and technology for the eleventh five year plan. http://planning commission.nic.in/aboutus/ committee/strgrp11/str11_sandt.pdf. Accessed 20 Dec 2016

91. Salamanca-Buentello F, Persad DL, Court EB, Martin DK, Daar AS, Singer PA (2005) Nanotechnology and the developing world. PLoS Med 2:383-386

92. UNESCO (2005) UNESCO science report 2005. UNESCO, Paris 